Conference Paper

\title{
Cyprian Ekwensi as a National, Urban or Pan-African Writer
}

\section{Umar Muhammad Dogondaji}

Department of Modern European Languages and Linguistics, Usmanu Dan Fodio University, Sokoto, Nigeria

\author{
Email address: \\ dogondajiumaru@yahoo.co.uk
}

\section{To cite this article:}

Umar Muhammad Dogondaji. Cyprian Ekwensi as a National, Urban or Pan-African Writer. International Journal of Literature and Arts. Vol. 4, No. 4, 2016, pp. 55-60. doi: 10.11648/j.ijla.20160404.13

Received: April 30, 2016; Accepted: June 25, 2016; Published: July 15, 2016

\begin{abstract}
Cyprian Ekwensi is, by any standard a major figure in African literature of the mid-twentieth Century. From its birth to date, Nigerian literature witnessed a tremendous growth and development with the early publications of the literary works of Chinua Achebe and those of Wole Soyinka respectively. However, despite the publication of about eight major novels by Cyprian Ekwensi, some literary critics still refuse to acknowledge the contribution and the importance of this popular Nigerian author. This paper attempts therefore to shed more light on the literary career of the author, his literary ideology as well as why some critics tag him to be a National, Urban or Pan-African Writer.
\end{abstract}

Keywords: Literature, National Writer, Pan-African Writer, Literary Ideology, Literary Works

\section{Introduction}

Nigerian literature is known throughout the world through the works of Chinua Achebe and those of Wole Soyinka. Besides these two renowned African writers, the literary works of Cyprian Ekwensi circulate in Africa so much so that his major novels are studied today in the sub-Saharan universities. Cyprian Ekwensi has written eight major novels: his novels present the three Nigerian societies: Burning Grass for instance, is an overview of Fulani traditional society of northern Nigeria, its culture and modes of life. Jagua Nana reflects the Western Nigerian sophisticated life while, the People of the City, tries to examine the moral decadence of life in Lagos. His biography shows that the author has written 33 short stories designated to teach moral education as well as serve as entertainment to Nigerian children.

In this article, we examine the biography of the author, his literary ideology as well as his literary vision on African literature in general and that of Nigeria in particular. The purpose of this article is to enable us to reflect on the literary contributions of the Nigerian writers in general and that of Cyprian Ekwensi in particular who has been tagged by some critics as being an urban writer because of his two earlier major novels which dealt with life in the cities and moral decadence.

\section{Cyprian Ekwensi's Literary Journey from 1921- 2007: Constance and Evolution}

Cyprian Ekwensi was born in Minna in northern Nigeria on September 26, 1921. His parents were Igbos but his father was then living in the north, working as a carpenter. His father was reputed to be great hunter in those days. Mr Ekwensi was educated in Nigeria, Ghana and England where he studied pharmacology at the Chelsea School of Pharmacy of London University. Afterwards, he as a teacher taught English, Chemistry, Biology, and Pharmacology in Nigeria, became a Pharmacist with the Nigerian Medical Service and then, suddenly, he switched to journalism where he became the Head of the features section of the Nigerian Broadcasting Corporation. In 1961, he became Director of information in Lagos, the post he occupied up to 1967 . He played a similar role in the secessionist Eastern Region during the Nigerian civil war (1967-1970). After the war, he operated a small Pharmacy in Enugu, started an exercise-machine business in Lagos and in 1976 became Managing Director of the Star Newspaper of Enugu. By this time, he had already published five novels-the most recent by then was Beautiful feathers and Iska-and a number of books for children as well as several Collections of Short Stories. 
Table 1. Literary publications of the author from the beginning of his writings to the end of his life. It consist of Short Stories for children, novellas, and his eight major novels.

\begin{tabular}{|c|c|c|c|}
\hline & Title of the Book & Date of Publication & Literary genre. Novel, or short story or children literature \\
\hline 1 & When love whispers & 1947 & Short Novel \\
\hline 2 & Ikolo, The Wrestler and other Igbo Tales & 1948 & Children Literature \\
\hline 3 & The Boa Suitor & 1949 & Children Literature \\
\hline 4 & The Leopard's Claw & 1950 & Children Literature \\
\hline 5 & People of the City & 1954 & Novel \\
\hline 6 & The Drummer Boy & 1960 & Short Story \\
\hline 7 & The Passport of Mallam Ilia & 1960 & Short Story \\
\hline 8 & Jagua Nana & 1961 & Novel \\
\hline 9 & Burning Grass & 1962 & Novel \\
\hline 10 & Yaba Rand about Murder & 1962 & Collection of Short Stories \\
\hline 11 & An African Night Entertainment & 1962 & Collection of Short Stories \\
\hline 12 & Beautiful Feathers & 1963 & Novel \\
\hline 13 & The Rainmaker and the other stories & 1965 & Collection of Short Stories \\
\hline 14 & The Great Elephant & 1965 & Children Literature \\
\hline 15 & Iska & 1966 & Novel \\
\hline 16 & Lokotown and Other Stories & 1966 & Short Stories \\
\hline 17 & Trouble in Form Six & 1966 & Short Stories \\
\hline 18 & Juju Rock & 1966 & Children Literature \\
\hline 19 & Cool Camp Boy & 1971 & Children Literature \\
\hline 20 & Samankwe in the Strange Forest & 1973 & Collection of Short Stories \\
\hline 21 & Samankwe and the Highway Robbers & 1975 & Collection of Short Stories \\
\hline 22 & Restless City and Christmas Gold & 1975 & Collection of Short Stories \\
\hline 23 & Survive the Peace & 1976 & Novel \\
\hline 24 & Rainbow-Tinted Scarf and other Stories & 1979 & Short Stories \\
\hline 25 & Divided we Stand & 1980 & Novel \\
\hline 26 & Motherless Baby & 1980 & Short Stories \\
\hline 27 & For a Roll of Parchment & 1986 & Short Stories \\
\hline 28 & Jagua Nana's Daughter & 1986 & Novel \\
\hline 29 & Behind the Convent Wall & 1987 & Short Stories \\
\hline 30 & Gone to Mecca & 1991 & Short Stories \\
\hline 31 & Masquerade Time & 1992 & Children Literature \\
\hline 32 & King Forever & 1992 & Short Stories \\
\hline 33 & Cash on Delivery & 2007 & Short Stories \\
\hline
\end{tabular}

In table 2, we are going to see clearly, the evolution of Cyprian Ekwensi's writings: from novella and children literature to his eight (08) major novels.

Table 2. Summary of the major novels of the author. Most of which were published by African Writers Series (AWS) and translated into other languages. For instance, Burning Grass and Jagua Nana were translated into French language under the titles: La Brousse Ardente and Jagua Nana respectively.

\begin{tabular}{lll}
\hline & Title & Date of Publication \\
\hline 1 & People of the City & 1954 \\
2. & Jagua Nana ( ${ }^{\text {st }}$ edition) & 1961 \\
3. & Burning Grass & 1962 \\
4. & Beautiful Feathers & 1963 \\
5. & Iska & 1966 \\
$6 .$. & Survive the Peace & 1976 \\
7. & Divided We Stand & 1980 \\
8. & Jagua Nana's Daughter (2nd edition) & 1986 \\
\hline
\end{tabular}

From table (1), it can be observed that Cyprian Ekwensi's literary career started since-he was 26 years old and it continued to the end of his life. He died in 2007 at the age of 95 when his last book was published.

\section{Cyprian Ekwensi's Literary Evolution: from When Love Whispers to Other Novels}

In August 9, 1974, in Enugu, Nigeria, Cyprian Ekwensi during an interview with a correspondent of Voice of America explained that his first published work was in 1947 when he wrote his first short novel titled When Love Whispers. He explained to the journalist that the book was banned from the convents because the girls use to have it under their pillows and read it. And there are very few literate Nigerians who will claim not to have either read When Love Whispers or to have not heard of it, even though it was published at a time when politics was talking point. However, the nation gave it an interesting recognition and it started vogue in Onitsha Market writing.

Nicholai L. (1981: 37) in his book titled Conversation with African Writers. In the series of interviews he had with the twenty-six African authors which included Cyprian Ekwensi himself and the author was quoted to have said in the preface of the book that "this little book of Mr Ekwensi is just the kind 
of which is needed at this very stage of our development as progressive unit of the human race ready to take our place among other nations".

During the interview on how Cyprian Ekwensi got started with his major novels, the author replied instantly by saying that:

Yes, I wrote Burning Grass but People of the City was the first book to be published. Now Burning Grass again was-it came out of my forestry experience. The vegetation of Nigeria is very interesting. In the south it is dense forest. In the north it is savannah and grassland. Now, because the north is grassy you have cattle-rearing on a very extensive scale. But you don't bring the grass to the cattle. The cattle go after the grass. And in our forestry days we lived in a part of the country which was infested by the tsetse fly that causes sleeping sickness. And one of the things we were doing was to clear the riverine areas and to reforest the open countryside. And it was here that I met these characters who inspired me to write Burning Grass. This story is a story of the wandering cattlemen of northern Nigeria who pursued the green grass wherever it is. The central character is an old man called Maisunsaye who is something of a sage and wisdom in his own community.

To buttress what the author says, we extracted from the novel the following passage.

When they begin to burn the grass in northern Nigeria, it is time for the herdsmen to be moving the cattle southwards to the banks of the great river. And the hunters, lurking on the edge of the flames with Dane gun, bow and arrow, sniff the fumes and train their eyes to catch the faintest flicker of beast hastening from their hiding places.

It is time too far for harmattan to blow dust into the eyes and teeth, to wrinkle the skin: the harmattan that leaves in its wake from Libya to Lagos a shroud of fog that veils the walls and trees like Muslim on a sheikh.

On the development of the People of the City, the writer explained further:

Now let us take People of the City. In the 1950's we had a radio station in Lagos called Radio Nigeria. So in those early days there was also a department called the Public Relations Department. The war was just ending, the Second World War, and there were a lot of veterans returning from Burma and India and so on. And the Public Relation Department thought of keeping these people entertained by having a magazine for them and also broadcasting stories on the air. I used to write short stories which I read, once every week. Later on I looked at these stories and found a pattern of city life. Then I decided that I would make these stories into one novel and started working on this. At the end of the voyage I had a manuscript. The manuscript was first called Lajide of Lagos but later on I called it People of the City because there were so many people of the city there. Most of the stories dealt with my immediate experiences. I lived in the centre of Lagos in Ebute Metta and I could see life in the raw. It was undisguised. This is how People of the City developed.

Furthermore, Cyprian Ekwensi explained to the journalist how Jagua Nana (the $1^{\text {st }}$ edition) came in to being: Jagua Nana developed out of two experiences. One when I used to travel frequently to Ghana on weekends. I had a lot of friends in the information. And the second experience was out of also living in Lagos and of the political era that came later on. So all this mixture is like building a house with cement and so on. This is part of the cement with which Jagua was built. Jagua Nana got her nickname Jagua because she was in the sleek, professional way, like the expensive British motor car the Jaguar although she is described as a luxury-loving prostitute in the novel. Jagua Nana after publication became very controversial because an Italian company wanted to make a film of it and there was a huge controversy about the character herself. Eventually the making of the film was postponed and then came the national crisis and the subject has not been reopened.

From the above explanation of Mr Ekwensi, we understand the nature of the controversy that came out as a result of the publication of Jagua Nana as follows: the nature of the controversy was that Jagua herself is a carefree woman who solicits male company for a price. But she happens to fall in love with a young teacher Mr Freddie Namme and send him to Britain to study law. And then he comes back and would not marry her, he is married to someone else. But Jagua is a very political animal and this whole book raises the question of the morality of Nigerian womanhood, from one point of view to interpretation. And from the other point of view, what kind of politics do we have? The following is extracted from the novel to buttress his above assertion. The passage shows one of the moments of Jagua Nana, a renowned prostitute but an active political animal.

I am still coming to the end of my story." They listened, and she went on: "You see the sort of people you will be voting for, if you vote O. P. one, you will be voting for people who will build their private houses with your own money. But if you vote for O. P. Two, the party that does the job, you will see that you women will never pay tax. Don't forget that O. P. Two will educate your children properly. But those rogues in O. P. One. They will send their children to Oxford and Cambridge, while your children will only go to Obanla. No: Obanla is still good to your children, because-oh!-how can your children find the space to be educated in Lagos schools, if O. P. One ever comes into power? No, your children will be sent into slummy suburbs. These people will open a hundred businesses using the names of their wives. But you? You will continue to sleep on the floor with grass mats while their wives sleep on spring mattresses. You will carry your things to market on your head, and while in the market you will be bitten by mosquitoes, and your children will be bitten by mosquitoes and develop malaria. And you will console yourselves that you are struggling. Tell me, what are you struggling for? Or are you going to struggle all the time? Now is the time to enjoy! On Saturdays you will kill a small chicken and call your friends. You will shake hips to the apala music and deceive yourself that you are happy. But look! The roof of your house leaks when it rains. The pan 
roofs are cracking with rust. There is no space in the compound where your children can play. The latrine is the open bucket, carried by night soil men who are always on strike, so the smell is always there. The bathroom is narrow and slimy and it smells of urine. You call that life!

On the critics that the author was painting the Nigerian woman as being too immoral, Cyprian Ekwensi explained how the Jagua Nana's saga generated tension and controversy. "But, in a controversy, one has two diametrically opposite points which are adamant. So some thought Jagua is immoral while some thought that there cannot be a finer person than Jagua, than the book. So that was how the controversy raged the whole nation as of that time". As per the development of his two other major novels namely the Beautiful Feathers and Iska, the author explained that The Beautiful Feathers in particular grew out of an evil proverb that all birds are alike when the feathers have been removed. So that no one should be deceived by the veneer of beautiful feathers because when you have plucked all the feathers, it is the same muscle and bone underneath. And Wilson Iyari, the central character of the novel, tries to unite the whole Africa, but his wife is being unfaithful to him and his family, his immediate family therefore remains his great problem and ironically, the author shows in the novel how a man who cannot govern his family is trying to govern the whole Africa in a Pan-African sense. So that's Beautiful Feathers.

Iska is just the story of a girl whose life is very short. In African context beliefs, there are certain people in this world who do not live long. They come into the world and they die very early but they come again, they keep on coming. The Yoruba's call them Abiku; the Igbo's call them Ogbanje. Now these people have certain characteristics. They are very kind. They do not take things very seriously. They are out to despise the things that other people value very dearly because they know they are not going to live long in this world. So this is Iska. Iska happens to be a Hausa word meaning wind. And the girl's life (the central character of the novel) fleet just like a wind.

Cyprian Ekwensi's literary career evolution from the theme of modern feminine characters to that of civil war that attracted national interest (1967-1970). After the war, he published his experiences and the experiences of his kinsmen (Igbo) in his two major novels namely: Survive the Peace and Divided We Stand.

On the development of his last novel titled Jagua Nana's Daughter, the author reintroduced the story of the Jagua Nana (the mother in the first edition) and that of Liza (her daughter in this second edition) in which the two women practice prostitution. The mother of the daughter combined one judge as their lover. The whole book raises the question of moral decadence that engulf our modern society.

\section{Thematic Evolution of the Major Novels of Cyprian Ekwensi}

The major themes in the novel of Cyprian Ekwensi are moral decadence that engulf the modern society sequel to its contact with the norms and values of the western world. The author uses a series of feminine characters to buttress his literary point of view. When he was asked to comment on the thematic evolution of his novels, Cyprian Ekwensi explained that: "My earliest themes dealt with the traditional society. Then succeeding that were the themes on the man on the two worlds. That was later on succeeded by the political theme. And we are now having this literacy explosion in which the new man of today is living in the computer age, he is living in the nuclear age-the new African who is far out in front. So these new themes are now dealing with the technological and almost, if you might like to call him, the electronic African. He is an executive and he is like his counterpart throughout the entire world except that he just happens to be an African. He is internationally travelled. He commutes to London or New York on a weekend and he is back as his desk the next morning. $\mathrm{He}$ is at an international conference where he purchases works of arts for two thousand Naira, that kind of thing. And he is trying to find his way in the international context with all the problems of the economy and fuel shortage and energy crisis and so on around him. And of course, love in its new sense, or non-love, family planning, and etc."1

In respect of the thematic evolution of his major novels, Cyprian Ekwensi explained further that:

My major themes are the values, or the non-value, in our society. In the village we still stick to the old concepts of respect for the elderly, love for children, morality. But in the city all these can go to hell as far as we have money. Once you have money, you are God. And even our last critical engagement which ended in war showed this characteristic very sharply, that even in the middle of suffering, people were still thinking of lining their pockets. Corruption or non-corruption begins and ends with that one word: money. I have been described as an urban novelist. If you are an urban novelist you cannot escape the point of view of money and non-values. In other words, the survival of the individual by any means.

\section{Cyprian Ekwensi: A National or Urban Novelist}

Literary critics of African literature tagged Cyprian Ekwensi to be and urban novelist entirely because his major novels dealt with the life in the city but Cyprian Ekwensi himself does not agree with them because he explained that:

No, I am a nationalist. Because I know Nigeria backwards. I have driven throughout the length and breadth of this country. There is no part of Nigeria I have not been to. The reason I have been called an urban novelist is that the bigger novels tend to deal with life in the cities where I have lived. But my smaller books for children deal with the whole country. So the critics like to stereotype a writer and this is tag they have found convenient for me. I do not argue with them.

The above assertion by the author can be true if we consider the composition and the regional spread of his eight major 
novels: Burning Grass for instance is a story of Fulani people of Northern Nigeria, their culture, customs, beliefs, religion and modes of life,. Iska, reflects on the life of Hausa people of Northern Nigeria in Kano and Kaduna towns respectively which he said he has written as a result of his stay in the north where he was born. People of the City, Jagua Nana and Jagua Nana's Daughter reflects the Western region life sophistication in general and that of Lagos in particular. His other two novels, Survive the Peace and Divided We Stand reflect on the life of the Igbo people in the Eastern part of the country. Thus, Nigeria is composed of three grand regions: North, East and West.

\section{Cyprian Ekwensi's Literary Vision: The Case of His Targeted Audience}

Nicholai L. (1981: 47) further explained that Cyprian Ekwensi's audience consist of an ordinary working class and in respect of that assertion, the author himself explains as follows;

Writing cannot be turned back now because it has already become part of our lives. It is indeed part of our lives. The Nigerians love a good story. They love spectacle. You only need to stand in a street corner where there has been a motor accident or something and everybody leaves whatever he is doing and is on the street. We like to see things. We like to hear scandalous things about people. We like to see how all these rich men are coming to a soggy end. And so on and so forth. And also we want to read about them. We want to see how we can acquire the wealth to build twenty-story buildings. And we also like to see those who have twenty story buildings being impeached for getting their wealth in corrupt way. So it is all part of the ebullience of life. It is all part of joy of living in the Africa today.

This vision of Mr Ekwensi concise with his perception of African literature in general and that of Nigeria in particular. However, for him, African literature can be defined in various perceptions. "My own definition of African literature is based on characters and psychology. This means that the main theme may be anthropological, traditional, and modern, but the traits, temperature and reactions of characters will be peculiarly African due to influence of tribe, culture, and history".

In respect of the content and the delimitation of his literature, Mr Ekwensi maintain that: "Cyprian Ekwensi's range embraces the Northern Savannah, the Eastern Village, Western Nigerian's sophistication and the City's decadence and degradation".

\section{Cyprian Ekwensi's Vision in Respect of the Problems and Prospects of Literary Writings in Africa}

Nowadays the problem that the writer faces is not as acute as the problem was when Cyprian Ekwensi began to write. At that time, economic problem hindered grossly the performance of the literary writer. However, according to Cyprian Ekwensi, the writer of today even if he is faced with some problems he is able to find employment in various media where he can be a writer, a broadcaster, information officer, public relations, etc. and with this he can earn a decent livelihood and if he wants to do any creative writing he can then do it at his own phase. Despite this development, Cyprian Ekwensi opined that the writer of today faces some serious problems and which he presented as follows:

The first problem is that

In some of these media, the problem of sensitivity, the political sensitivity. In developing countries as a whole there is a great deal of sensitivity about exposure of delicate issues when those issues are still delicate. This is quiet understandable in that these exposures tend to prejudge the issues. And even if I were in authority I would not like them. Therefore, the writer must bide his time and write in a manner which, while exposing the truth, is also able to help achieve the end he is aiming at. It is no use messing up everything simply because you must write about it, because you will be defeating the very end you are setting out to achieve.

Then the other problem is the problem for book writers: publication. There are lots of printing establishment setting up but publishers are still few and far between. Some publishing houses have started up in East Africa. Here in Nigeria we have some indigenous publishing companies and some branches of international publishing companies. For the writer my own advice would be to try to expose your work as much as possible by getting on the international network. But at the same time you must have your roots at home because eventually this is where you belong. A Russian writer should be happiest in Russia and writing for his own people. So should also be an African writer. Recognition in your own home is, I think, one of the big achievements and this also brings about recognition outside but it can also work the other way around.

\section{Literary Awards and Immortalisation of Cyprian Ekwensi}

Sequel to his enormous contribution to the development of African literature in general and that of Nigeria in particular, Cyprian Ekwensi was given in 1968, the International Literary Award of Hammarskjöld. Nationally, he was equally recognised for his contribution to Nigerian Literature because the Abuja Centre for Arts and Culture was renamed after him. It is now known as Cyprian Ekwensi's Centre for Arts and Culture. He was equally pioneer member of the Nigerian authors Association. The above mentioned Association has stated 16 November, 2007 to award Cyprian Ekwensi a price for the total collection of his literary work. Sequel to his death before the stated date, the above award was awarded to him after his death on $7^{\text {th }}$ November, 2007. Denisse Coussy in his critical work titled Nigerian English Novel, while making reference to the Nigerian writers and their contribution to the 
development of African literature in general and that of Nigeria in particular, explained that Nigerian writers were convinced beyond reasonable doubt of the importance of national literature and that was why they collectively wrote books that suit the new era of the national development of their country. He said their writings put across the aspiration, of a nation that was ready to take its rightful position among the other independence nation.

Cyprian Ekwensi a popular Nigerian writer, was convinced of the above need that is why he adopted a literary style and introduced the literary themes that satisfy the needs and aspirations of his people most especially in the new era of contact with the new western values which sweep the old African traditions. This wind of change which blew throughout Africa was what motivated the author to write his major novel titled Iska which he wrote in 1966, six years after Nigeria has got its independence on $1^{\text {st }}$ October, 1960.

\section{Conclusion}

In conclusion, the article establishes the fact that Cyprian Ekwensi was a prolific Nigerian writer. His literary works have cut across not only English speaking African countries but also the francophone West African countries with many of his Short stories and articles published in journals throughout the English speaking world. His books were translated into many languages, some of his major novels for instance Burning Grass and Jagua Nana were both translated into French. Thus, his literary work have continued to draw the attention of the researchers not only in African Universities but throughout the world because Cyprian Ekwensi was not only a Nationalist Nigerian writer but a Pan Africanist who believes in reuniting Africa through the promotion of His literary ideology of African personality to which he and other English speaking writers were attached and committed to promote through their writings.

\section{References}

[1] Ekwensi, C. (1954), People of the City, London: Heinemann.

[2] Ekwensi, C. (1961), Jagua Nana: London: Hutchinson.

[3] Ekwensi, C. (1962), Burning Grass: A story of the Fulani of Northern Nigeria.-Heinemann, London:

[4] Ekwensi, C. (1963), Beautiful Feathers, London: Hutchinson.

[5] Ekwensi, C. (1966), Iska, London: Hutchinson.

[6] Ekwensi, C. (1976), Survive the Peace, London: Heinemann.

[7] Françoise, B. (1978.) La Brousse ardente: Histoire Fulani du Nord du Nigeria.-Roman traduit de l'anglais Paris: Présence Africaine.

[8] Ekwensi, C. (1980), Divided We Stand, Enugu: Fourth Dimension Publishers.
[9] Ekwensi, C. (1986) Jagua Nana's Daughter, Ibadan: Spectrum Books.

[10] Françoise, B. (1988), Jagua Nana: Roman traduit de l'anglais par.- Publié avec le concours du Centre Culturel Français de Lagos.-Nigeria. - Paris: Présence Africaine.

[11] Ekwensi, C. (1947), When Love Whispers, Yaba, Nigeria.

[12] Ekwensi, C. (1947), Ikolo, the Wrestler and other Igbo Tales, London:

[13] Ekwensi, C. (1950), The Leopard's Claw, London:

[14] Ekwensi, C. (1960), The Drummer Boy, London: Cambridge University Press.

[15] Ekwensi, C. (1962), The Passport of Mallam Ilia, London: Cambridge, University Press.

[16] Ekwensi, C. (1962), An African's Night Entertainment, Lagos: African University Press,

[17] Ekwensi, C. (1962), Yaba Randabout Murder, Lagos: Tortoise Series books.

[18] Ekwensi, C. (1965) The Rain-Maker and other Stories, Lagos: Africain University Press.

[19] Ekwensi, C. (1965), The Elephant-bird, London: Nelson.

[20] Ekwensi, C. (1966), The Boa Suitor, London: Nelson.

[21] Ekwensi, C. (1966), Trouble in Form, London: Cambridge University, Press.

[22] Ekwensi, C. (1966), Juju Rock, Lagos: African University Press.

[23] Ekwensi, C. (1966), Lokotown and other Stories, London: Heinemann.

[24] Ekwensi, C. (1975), Restless City and Christmas Gold with other Stories, London: Heinemann.

[25] Ekwensi, C. (1980), Motherless Baby, Enugu: Fourth Dimension Publishers.

[26] Chinua, A. (1958), Things Fall Apart, London: Heinemann.

[27] Chinua A. (1964.), No Longer at Ease, London: London: Heinemann, Arrow of God, (1964) - London: London: Heinemann.

[28] Coussy, D. (1988) Le roman nigéran Anglophone: Paris: Edition Silex.-.

[29] Dogondaji U. M. (2016) La Culture Peulh à Travers La Brousse ardente de Cyprian Ekwensi - International Conference on Fulfulde studies on the theme: Fulbe Language Literature and Culture - organized by the Centre for Research in Nigerian Languages and Folklore, Bayero University Kano-Nigeria.

[30] Nicholai L. (1981) Conversation with African Writers. Interviews with twenty-six African authors. - Washington: VOA. PP 37-47. 